\title{
構造目地を有する鉄筋コンクリート造腰壁付き骨組の力学的特性 に関する研究
}

\author{
そのI一腰壁付きはり・柱十字形骨組の加力実験について
}

\section{1. 序}

鉄筋コンクリート造建物には，構造計算時に地震抵抗 機構とされる耐震壁以外に, 意匠・機能・経済性能の 種々の理由によって,たれ壁・腰壁・そで壁と呼ばれる 小壁体 (以後, 雑壁と総称する) がよく設けられる。し かしながらここれら雑壁が，地震時に骨組の変形を拘 束し建物の挙動や破壊形式に大きな影響を与えること

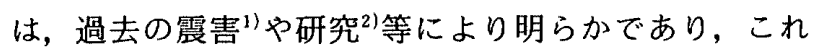
らの雑壁に対する構造計画面からの解決策の提案が必要 とされている。中低層の通常の鉄筋コンクリート骨組内 の腰壁について考えると, 腰壁の存在は柱のせん断破壊 につながりやすいマイナス面だけでなく, 腰壁の存在は 建物の保有耐力を高めるプラス面もある3)ので, 腰壁の 高さを調節するのも一種の解決策に属するが, 最近, 腰 壁亡柱との接合ディテールのくふうによって柱のせん断 破壊を防止し, かつ, 骨組の崩壊メカニズムの形成と保 有耐力の算出を明快にする方向での解決策を目標とする ことに関連した研究が多い。現在までに提案されている ディテールは, 下記の 3 種類に大きく分類される。

A. 腰壁付き骨組で腰壁と柱の接合部に完全縁切りし た空間を設ける方法。文献 4)，5）に示す研究が ある。

B. 雑壁と骨組の接合部の壁に局部的欠損を設ける方 法。柱と腰壁の接合部分に電磁波を照射すること によってコンクリートを脆弱化させることを検討 した初期の研究7をはじめ，スリット型の断面欠 損を設けるものを含め文献 6)，8)－11），16）に 示す種々の提案と研究・夷施例がある。

C．コンクリートより脆弱な材料を雑壁と骨組の接合 部に設置する方法。文献 12）に示す研究がある。

また，実施面までをも考慮すると，いずれのディテー ルにおいても, 力学的特性のほかに一般の RC 壁が有

本報告の一部は, 昭和 61 年度日本建築学会学術講演梗概集構 造 II で発表した。

* 九州芸術工科大学 教授.工博

** 九州芸術工科大学 助手・工修 (昭和 62 年 2 月 9 日原稿受理)

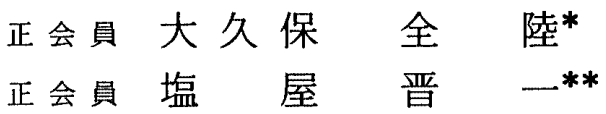

する防水・耐火・遮音・耐久性等の機能も要求されるこ とが多いが，これらの諸点に関する研究例 ${ }^{13)}$ は極めて少 ない。

本研究では, 防水・耐火・遮音性能等に対する処置も 容易で，かつ，力学的特性の改善を目的とする上記 B のディテール (以後, 構造目地と呼ぶ) 設計法の開発を 目標とし，まず，腰壁付き骨組を対象とする。

この構造目地を有する腰壁付き骨組では，構造設計の 際,一般にはり降伏先行が設定されるが, この場合, 構 造目地部の曲げ圧縮抵抗の違いによって, はりの復元力 特性（腰壁が曲げ㴼力を受ける時の抵抗モーメントと 曲率との関係) として図一 1.1 に示すような 3 タイプが 考えられる。

Type I : 構造目地部の曲げ圧縮抵抗が大きく, その破 壊によって抵抗モーメントが急激に低下する。

Type II：構造目地部が, ある程度, 破壊するが, はり 主筋の曲げ降伏によって抵抗モーメントが決定 し，その值が，比較的安定した状態で腰壁のな いはりの抵抗モーメントを上回る。

Type III：構造目地部が早期に破壊し, 腰壁の存在がは りの抵抗モーメントにほとんど影響しない。 骨組の保有耐力を適切に評洒する観点からは Type II，

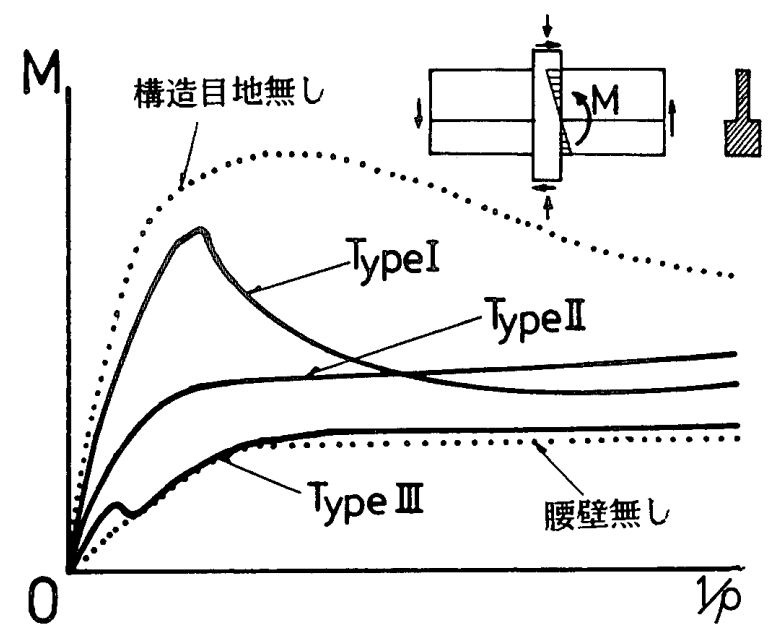

図一1.1 構造目地を有する腰壁付きはりの力学的特徴（腰壁が 曲げ压縮の時） 
IIIが好ましく，また，腰壁の影響を無視しようとすると Type III となるこれらの復元力特性に影響を与える要 因として下記の事項が挙げられる。

1) 柱，はり断面寸法と主筋量

2）腰壁の寸法と壁横筋量

3）構造目地の形状・寸法・位置

本論文では，上記の要因 3）に着目し，構造目地の形 状とその寸法がはり降伏形の腰壁付き骨組に及ぼす影響 を調べるために, 種々の構造目地を腰壁と柱の接合部に 設けた腰壁付きはり・柱十字形部分骨組で破壊実験を行 い, 各骨組について破壊性状, 力学的特性, および, 復 元力特性の検討を行う。

\section{2. 実験計画}

\section{1 構造目地の種類}

試験体に設けた構造目地の詳細を図一2.1に示す。対 象とした構造目地は基本的に下記の 3 タイプである。

i ) 円形空洞目地 (No.3 No.5)

壁内部に円形の空洞を形成し，両側壁面に収縮きれつ 誘発目地を併用するタイプで，欠損部の仕上げと防水対 策が容易と考えられる。ただし，No. 5 の目地は, 腰壁 横筋が引張または圧縮力を交互に受けることにより目地 部コンクリートの破壊を促進させる狙いで，腰壁横筋を 折り曲げ配筋とした。

ii ) 一面せん断目地 (No.6, No.7)

両側壁面から矩形の欠損をもうけ，目地部の圧縮断面 を零とし，抵抗断面をせん断面のみとするタイプで，応 力伝達形式が主にせん断応力によるものであるため，コ ンクリートの圧縮強度とせん断強度の比から, 低荷重レ

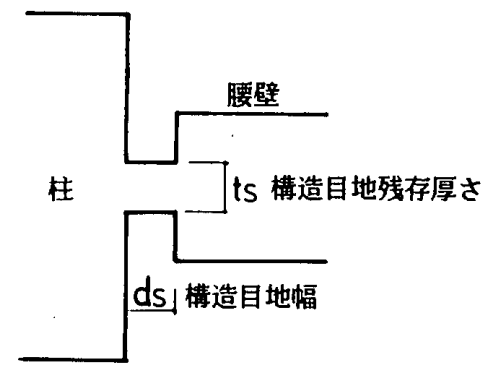

図一2.2 一般的な矩形目地

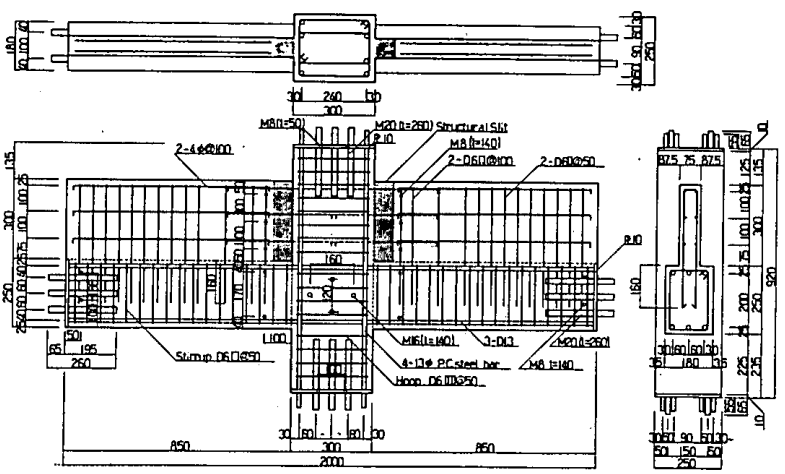

図一2.3 試験体の形状・寸法・配筋

ベルで目地部の破壊が予想される。

iii）圧縮せん断目地（No.8）

一面せん断目地の形状に類似したもので目地部の王縮 抵抗断面を残したタイプ。図一 2.2 に示す矩形目地のコ ンクリート強度は, スリット幅 $(d s)$ と厚さ $(t s)$ の 比によって圧縮強度の増加が生じる(1) のに対して，この タイプは両側壁面の矩形欠損をずらすことにより見掛け 上のスリット幅と厚さの比を大きくし, 強度増加を低減 する狙いがある。

上記の目地欠損部の作製につい
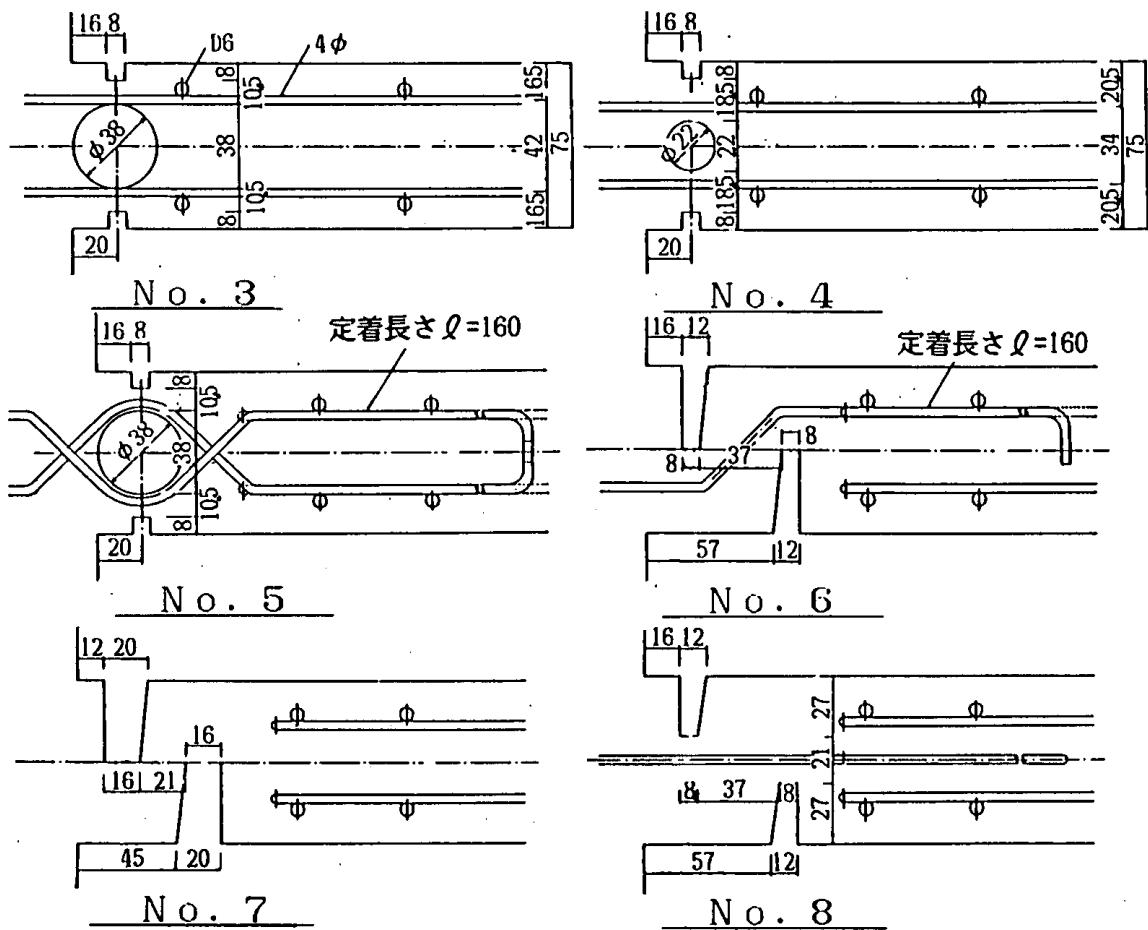

図-2.1 構造目地詳細 ては,コンクリート打設時に円形 空洞は市販の薄肉塩ビパイプを, 矩形欠損は木製の角材を用いた。 なお，実構造物においては，円形 空洞目地の薄肉塩ビパイプは埋め 込まれたままであることが予想さ れるが，本実験では，観察のため に除去した。

\section{2 試験体}

試験体は, 学校建築や病院建築 で見られるような鉄筋コンクリー 卜造建物の腰壁付きフレームを想 定し，実大の約 $1 / 2.5$ とした。

図一 2.3 に腰壁付き試験体の基 本形状と配筋状況を示す。同図中 の腰壁のハッチした部分に図一 2.1 の各種構造目地を設けた。各 試験体を一覧して表一 2.1 に示 
表一2.1 試験体名と目地部の特徴

\begin{tabular}{|c|c|c|c|c|}
\hline 践体名 & 目地の種䫛 & 目地形状 & 梢造目地及び試歌体の特微 & \multirow{5}{*}{ 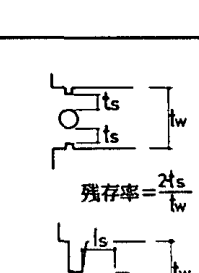 } \\
\hline No. 1 & 腰壁なし & & 比较用の基本形、ばり曲け降状先行 & \\
\hline No. 2 & 䁏硅付き & $\overline{\underline{L}}$ & 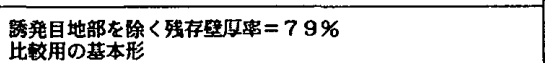 & \\
\hline No. 3 & 円形空洞 & 告 & 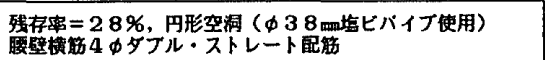 & \\
\hline No. 4 & 円形空洞 & $\frac{2}{0}$ & 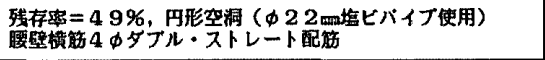 & \\
\hline No. 5 & 円形空洞 & 牙 & 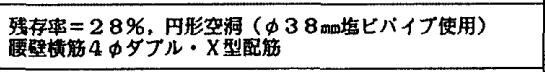 & \\
\hline No. 6 & 一面せん断 & $\frac{\sqrt{2}}{\sqrt{\Omega}}$ & 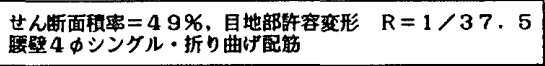 & \\
\hline No. 7 & 一面せん断 & $\sqrt{\Omega}$ & 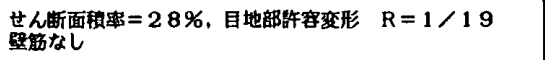 & \\
\hline No. 8 & 圧蛨せん断 & $\frac{\sqrt{r}}{\Gamma}$ & 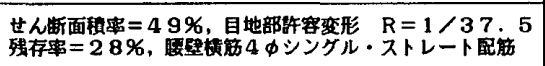 & \\
\hline
\end{tabular}

\section{4 加力・测定方法}

加力装置を図一2.4 に示す。加 力は図一2.5.1に示すように柱の 上下端が水平移動しない状態で, 左右はり先端のたわみを等しく保 ちながら,変形漸増方式で行った。 この加力方法は, 図一2.5.2 に示 すようにはり先端の加力点が上下 に移動せず，柱頭が水平移動する 場合の忘力・変形状態と等価であ る。同図中の式で柱とはりの性状 が含まれた層せん断力神之層間 変形に変換することができる。柱
表一2.2 使用材料の力学的特性

\begin{tabular}{|c|c|c|c|c|}
\hline \multirow{2}{*}{ CONCRETE } & $\left.F_{c}(\mathrm{~kg} / \mathrm{cm})^{2}\right)$ & $c \varepsilon B(\%)$ & Fsp $\left(\mathrm{kg} / \mathrm{cm}^{2}\right.$ & $E c(\mathrm{~kg} / \mathrm{cm}$ \\
\hline & & 0.25 & & $\times 1$ \\
\hline \multirow{3}{*}{$\begin{array}{l}\text { STEEL } \\
\text { BARS }\end{array}$} & $13 \phi *$ & 20 & 820 & \\
\hline & D 13 & 3500 & 5050 & $\times 10^{6}$ \\
\hline & D6 & $\frac{3820}{3920}$ & 5580 & $1.79 \times 10^{6}$ \\
\hline & & & & \\
\hline
\end{tabular}

す。No.1, No. 2 は比較用試験体で, No. 3 No. 8 が構 造目地を有する試験体である。

試験体の配筋は, 構造目地を設けない腰壁付き試験体 既往の曲げおよびせん断終局強度式で設計し，ほかの試 験体についてもこれと同じ配筋とした。なお，柱主筋に ついては, 曲げ降伏しないように高張力䤡（PC 鋼棒 $13 \phi)$ を用いている。

\section{3 使用材料の力学的性質}

コンクリートおよび鉄筋の材料試験結果を表一 2.2 に 示す。コンクリートには粗骨材寸法 $10 \mathrm{~mm}$ の生コンを 用い，打設時のスランプは $18 \mathrm{~cm}$ であった。コンクリー 卜は横打ちとし, 腰壁とはりおよび柱は一体的に打設し た。

帯筋・助筋・腰壁縦筋に用いた D 6 と柱主筋 $13 \phi$ の 降伏点強度は，残留ひずみ $0.2 \%$ に相当する値である。

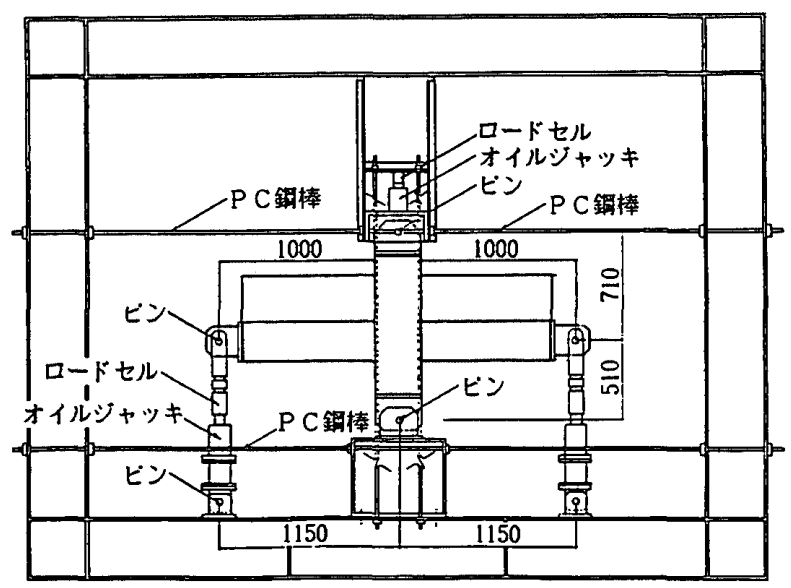

図一2.4 加力装置 (No.2) で腰壁付きはりの曲げ降伏が先行するように
の軸力は $N=15$ ton $\left(N / b D=20 \mathrm{~kg} / \mathrm{cm}^{2}\right)$ を目標とし たが，実験中に $N=15-1.1$ (ton) $\sim 15+2.3$ (ton) の範 冊での変動が生じた。載荷プログラムを図一2.6に示す。

左右はりの荷重と柱軸力の測定は，オイルジャッキ先 端にとりつけられたロードセルによった。変形の測定は, 図一2.7に示すように変形測定用ホルダーを接合部パネ ルに取り付けて柱はりの曲げせん断変形を測定したほ か, はり危険断面位置での腰壁付きはりと柱との間の相 対水平変形を測定した。また, 柱・はり主筋, 腰壁横筋 等のひずみをひずみゲージで測定した。

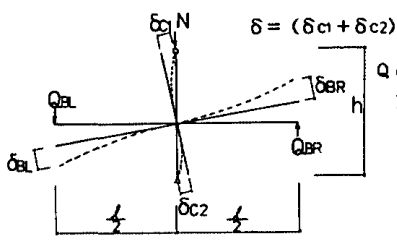

図一2.5.1 実験による荷重・ 変形

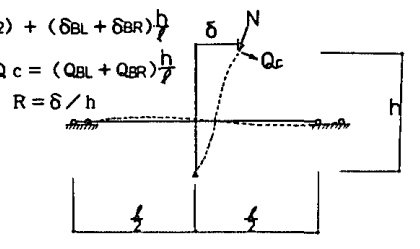

図一2.5.2 層せん断力・ 層間変形

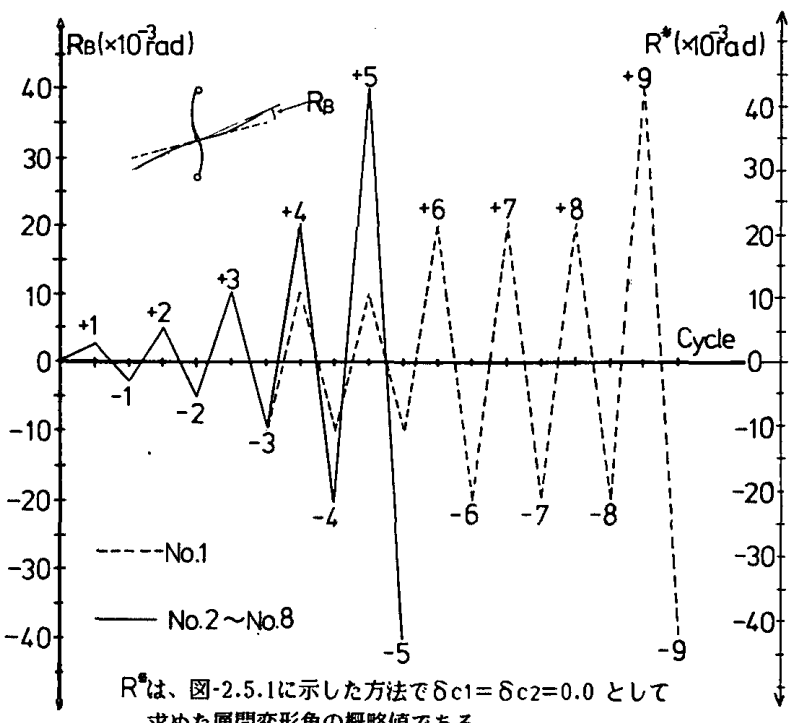
求めた首間変形角の概略値である。

図一2.6 載荷プログラム
注1）層せん断力 $Q_{c}$ は，軸力 $N$ に対して垂直な方向と定䣡する。 


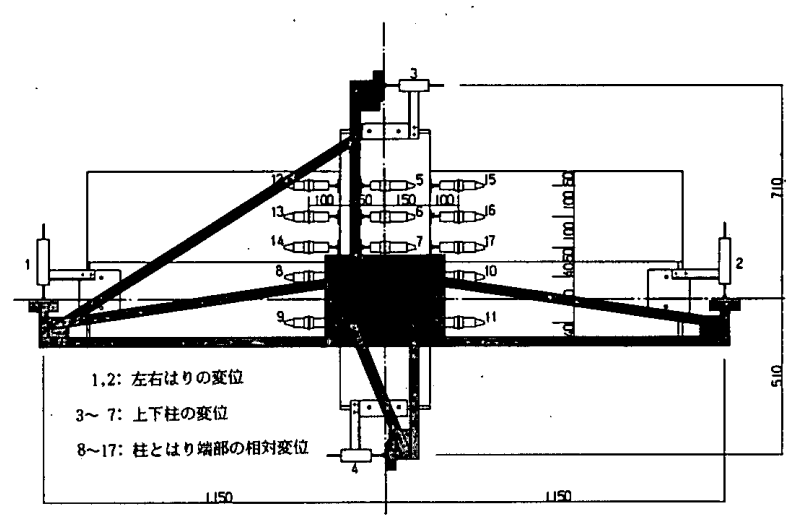

図一2.7 変形測定方法

\section{3. 実験結果}

\section{1 破壊経過}

図一 3.1 に各試験体の実験最終時のひび割れ状況を示 す。以下に各試験体の破壊概況を記す。各サイクルの層 間変形角の概略值を図一 2.6 に示す。

腰壁無しのNo.1 : \pm 1 サイクルで左右はり ${ }^{\text {世22 }}$ に危険 断面位置から材中間まで曲げひび割れが生じ，士2サイ クルで上柱に曲げひび割れ，接合部にせん断ひび割れが
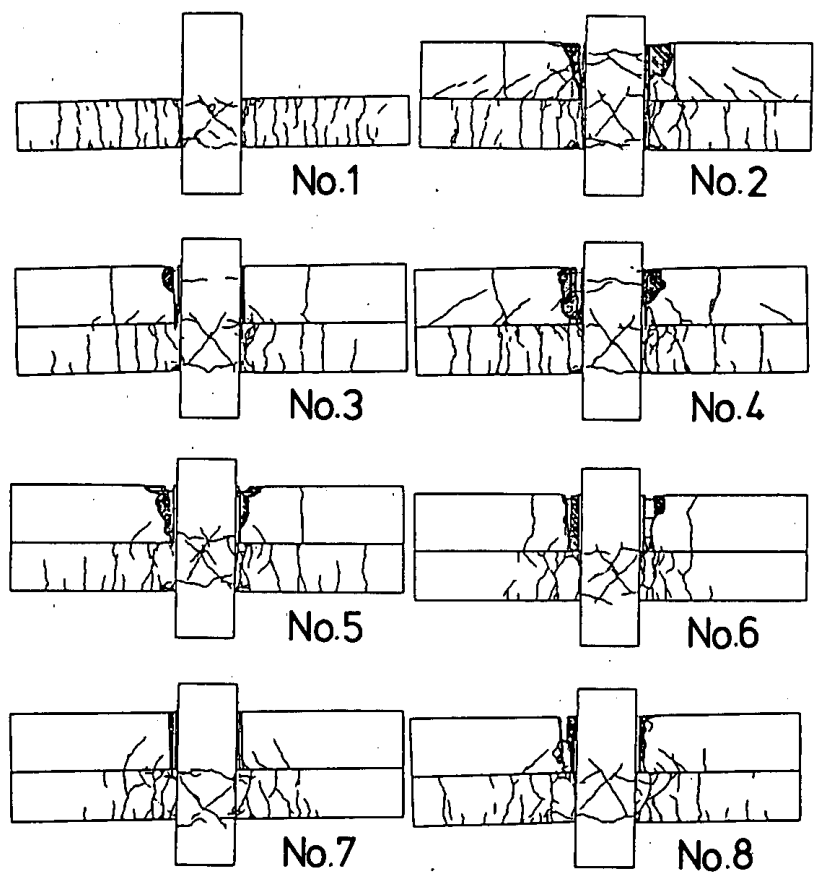

図一3.1 各試験体の最終ひび割れ状況

注2）本論では，右図に示すように+1サイクルの加力時に腰壁が，曲げ戌 縮側となるはりを右はりと，また，腰壁が曲げ引張側となるはりを 左はりと呼ぶ。

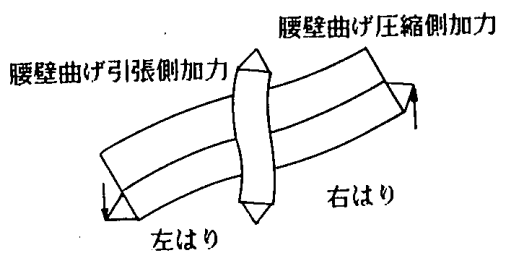

+1 サイクル加力時
それぞれ生じた。土3サイクルで曲げ引張側はり主筋が 降伏した。この時, 曲げ圧縮側主筋は, 降伏ひずみ $\varepsilon_{y}$ の $23 \%$ の引張ひずみであった。

構造目地無しのNo. 2：士2 サイクルで左右はりの腰 壁頂部がわずかに圧壊が生じた。土3サイクルでは，腰 壁が曲げ圧縮側となるはりの上下主筋が降伏し最大耐力 に達した。この時点では, 腰壁頂部から下方に約 $2 \mathrm{~cm}$ の範囲に圧壊が生じているが, 曲げ圧縮応力を受けてい る腰壁部分のコンクリートはまだ健全である。最終サイ クル時の $R=+1 / 35$ で, 腰壁コンクリートが腰壁頂部 から約 $20 \mathrm{~cm}$ 圧壊はく落し，上柱の接合部近傍に曲げ ひび割れが生じた。

円形空洞目地の No. 3 No. 5：士1 サイクルでNo.3, No. 5 は, 左右はりで腰壁頂部から約 $3 \mathrm{~cm}$ 目地の圧壊 が生じたが，No.4は腰壁頂部表面でわずかに圧壊した のみであった。土2サイクルでは, No.3, No. 5 は, 腰 壁が曲げ圧縮側となるはりの下端主筋の降伏（上端主筋 は $\left.0.5 \times \varepsilon_{y}\right)$ と反対側はりの上端主筋の降伏が起こり, 最大耐力に達した。この時点で, 目地部の圧壊は, 腰壁 頂部から No. 3 で約 $18 \mathrm{~cm}, N 0.5$ で約 $20 \mathrm{~cm}$ の位置ま で進展した。これに対しNo.4は目地の圧壊進展は約 $7 \mathrm{~cm}$ で, 腰壁が曲げ圧縮側となるはりの下端主筋は降

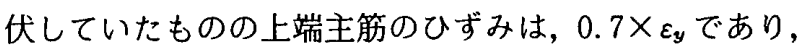
まだ最大耐力には達していない。 33 サイクルになると， No. 4 では, 腰壁曲げ圧縮側となるはりの上下主筋と反 対側はりの上端主筋が降伏し最大耐力に達した。この時, 目地の圧壊は腰壁頂部から約 $18 \mathrm{~cm}$ 進展している。 No. 3, No. 5 は, 目地部の圧壊が, 腰壁頂部から約 25 $\mathrm{cm}$ の位置まで進展し，上柱の接合部近傍にも曲げひび 割れが生じた。最終サイクルでは, No. 5 の腰壁コンク リートのはく落状況は腰壁下方から頂部に向かって直線 的に広がっていてNo.3 と異なり, 腰壁横筋の折り曲げ 配筋の影響が現れている。No.4の圧壊は, $25 \mathrm{~cm}$ の位 置まで進展していた。

一面せん断目地の No. 6, No.7: \pm 1 サイクルで左右 はりの曲げひび割れが生じたが，このひび割れは危険断 面近傍（はり材長の $10 \%$ の範囲）に限られていた。ま た，腰壁が圧縮となる側の目地では一面せん断ひび割れ が発生し, 腰壁頂部から $17 \mathrm{~cm}$ まで進展した。No.6で は 3.5 節で後述する目地部の局部的な面外曲げによるひ び割れが左右目地で生じ，腰壁頂部から約 $20 \mathrm{~cm}$ まで 進展した。+2サイクルでは, No. 6 の目地部の面外曲 げひび割れは, 腰壁頂部から $25 \mathrm{~cm}$ まで進展し, No. 6, No.7 の一面せん断ひび割れも進展しているものと推測 されるが，この目地形式では表面からは目視できない。 両試験体とも腰壁曲げ圧縮側のはりで下端主筋が降伏 (上端主筋のひずみは, No.6で $0.3 \times \varepsilon_{y}$, No.7で $0.25 \times$ $\left.\varepsilon_{y}\right)$ し最大耐力に達した。No.6の面外曲げひび割れも 
完全に腰壁下方まで達した。4サイクルでは，No.6の 目地部コンクリートが面外曲げひび割れと一面せん断ひ び割れとによって直方体形に分割されたが，腰壁横筋の 付着によってはく落はしなかった。これに対し No.7で は, 一面せん断ひび割れだけで変形が吸収され，目地近 傍の腰壁には，ほとんど破壊は生じていない。No.6の 最終サイクルでは, 腰壁圧縮側のはりで目地が閉塞した。 腰壁が曲げ引張側となる加力時には, 折り曲げ配筋され た腰壁横筋が伸び, 前述の 4 サイクルで分割された直方 体のコンクリートをはく落させた。

王縮せん断目地の No. 8：士1サイクルで, 腰壁頂部 で目地にわずかに斜め圧縮によるせん断ひび割れが生じ た。 2 サイクルで, 腰壁が曲げ圧縮側となるはりでは 主筋が降伏することなく, 目地部の圧縮抵抗が最大とな り, 部材の最大耐力に達した（下端主筋で $0.85 \times \varepsilon_{y}$, 上端主筋で $\left.0.25 \times \varepsilon_{y}\right) 。 \pm 3$ サイクルでは, 腰壁が曲げ
圧縮側になるはりで下端主筋が降伏した（上端主筋で $\left.0.45 \times \varepsilon_{y}\right)$ 。目地の圧縮せん断ひび割れは腰壁頂部から 約 $17 \mathrm{~cm}$ まで進展していた。土4 サイクルでは, 前述の No. 6 と同様に目地コンクリートが分割され，最終サイ クルではく落したが，No.6より激しくなかった。同サ イクルで左右はりの目地が閉塞した。

\section{2 層女九断力・変形関係}

図一 3.2 に各試験体の層せん断力・層間変形関係をそ れぞれ示す。

腰壁無しのNo. 1 は, 実験計画時に予想されたとおり， はりの引張鉄筋曲げ降伏 $(R=1 / 140)$ によって耐力が 決定し,大変形に至っても安定した耐力を保持していた。 \pm 3 サイクル以降のループ形状で，変形レベルが大きく

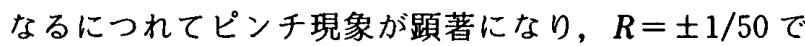
の繰り返し加力により $30 \%$ の耐力低下を示している。

構造目地無しのNo.2 は, さ2 サイクルでほぼ同時に

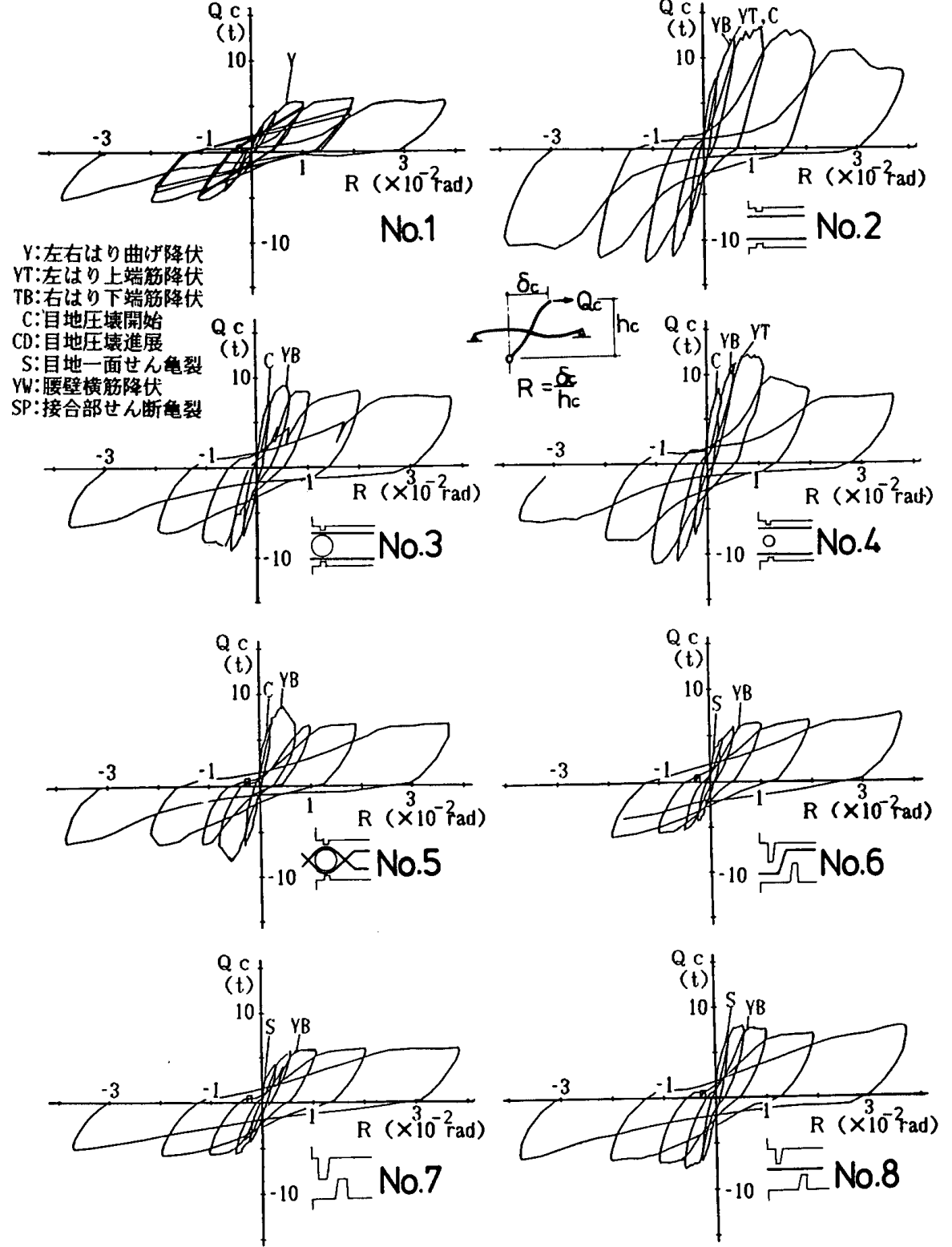

图一3.2 各試験体の層せん断力・層間変形曲線

左右はりの曲げ引張側主筋が降 伏し剛性低下を示している。土 3サイクルになると，腰壁曲げ 圧縮側はりの上端主筋が降伏し 耐力が決定している。腰壁圧壊 の進展により耐力低下が生じた のは, 比較的大きな変形レベル $(R=1 / 46)$ である。この点に 関しては，試験体がはり主筋降 伏形に設計されていること，お よび腰壁縌筋に用いたへ形筋に よって腰壁コンクリートが拘束 されたこと等によるものと考え られる。

円形空洞目地の No. 3 No. 5 は, No. 3, No. 5 が2サイクル で左右はり曲げ引張側主筋の降 伏で耐力が決定しているのに対 し，No.4は土3サイクルで腰 壁曲げ圧縮側はりの上下主筋の 降伏で耐力が決定している。最 大耐力以降, 3 体とも変形の増 加に従って圧縮側目地の破壊が 進展して耐力低下を生じたが, No. 3 の復元力特性は Type II に近い。No. 5 は腰壁横筋の折 り曲げ効果により耐力低下が特 に急激であり，その復元力特性 は Type Iに属する。

一面せん断目地のNo.6, No.7には目地寸法之配筋方法 の違いがあるが， 2 体とも腰壁 
目地部の一面せん断破壊が極めて早期に小荷重レベルで 起り, 腰壁の存在が骨組の保有耐力にほとんど関係しな いはり降伏形の安定した復元力特性を示している。2 体 ともはり降伏時の耐力および変形は，No.1 試験体とほ ぼ同等であり復元力特性 Type III にほぼ近い。なお, No. 6 では, 大変形域 $(R=1 / 30$ 以降 $)$ で目地部が閉塞 して腰壁に圧縮力伝達が起こりはじめ,これによって荷 重が増加する現象が現れている。

压縮せん断目地のNo.8では，耐力が一面せん断型目 地の No. 6 およびNo.7 より高まるが, 目地部圧縮せん 断破壊後, 急激な耐力低下は見られず良好な復元力特性 を示し, 復元力特性 Type II でNo. 6 と同様に構造目地の閉塞による荷重増加が生じ ている。

\section{3 ループ性状}

小谷等は，完全スリットを有する腰壁付き骨組では， 腰壁付きはりの変形がスリット部に集中し，降伏後接合 部内ではり主筋の付着劣化を促進させ, 復元特性に顕著 な逆 $S$ 性状を生じることを指摘している(5)。ここでは, 構造目地設置によるループ性状への影響を検討する。

\subsection{1 ループ形状}

図一3.3.1 と図一 3.3 .2 に各サイクルのループ面積と 変形の関係を，図一3.4に3，4，5サイクの無次元化し たループをそれぞれ各試験体について示す。無次元化は 各サイクルの最大変形時の荷重と変形で行ったが，最大 変形に達する途中で耐力低下を生じたものについては, 各ループの最大荷重と最大変形で行った。

3サイクルでは, No. 5 のループがほかに比べて細く なっており，ループ面積からもこのことが確認できる。 ほかの試験体はあまり差が見られずNo.1に近いものと なっている。

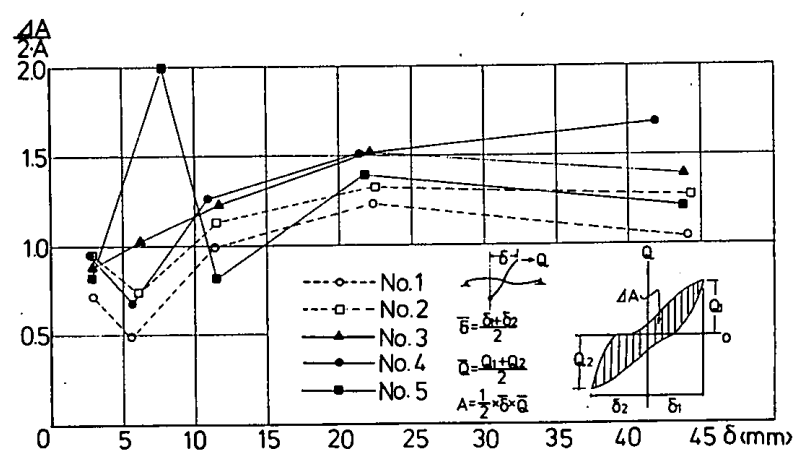

図一3.3.1 No.1〜No.5のループ面積比

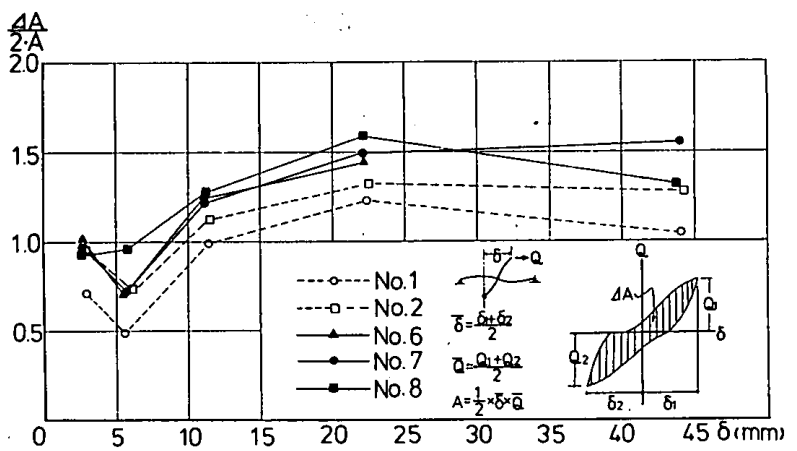

图一3.3.2 No.1, No. 2 と No. 6〜No.8のループ面積比

4 サイクルになると, No.2で負加力時に極端なピン 于現象が生じているが，これは正加力時に図一 3.5 のよ うに開口したはり下端の曲げひび割れの閉口が遅れるこ とによるものである。ほかの試験体はNo.1 とほぼ同じ である。No. 2 がループ面積比でNo.1 より大きいのは, 面積比を求める際に各ループの最大変形を基にしたため である。

5 サイクルでは, No.1〜No.5 で同程度のピンチ現象 が生じたが, No.6〜No.8は比較的良好なループになっ ている。なお，No.1では 3，4の各サイクルレベルで
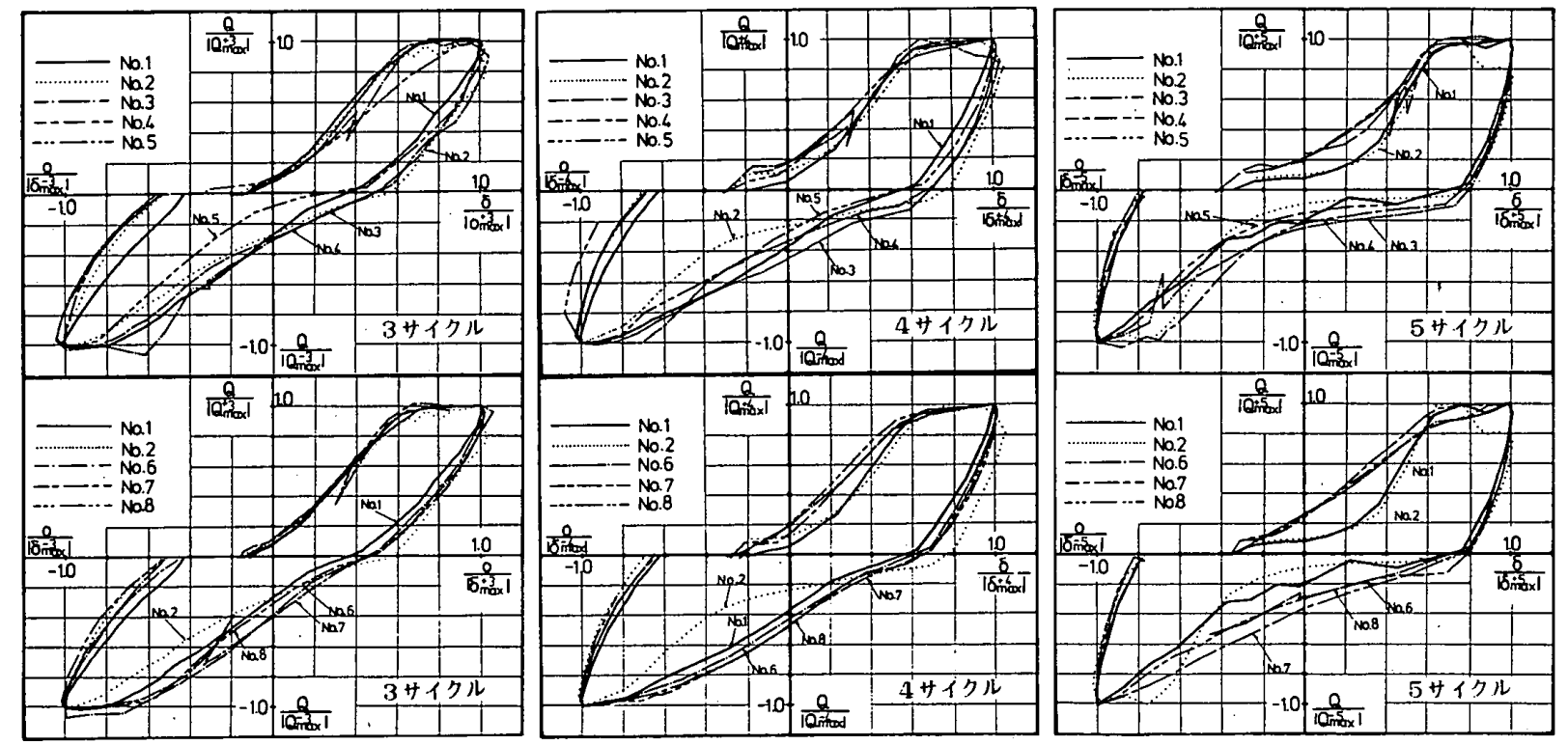

図一3.4 $R \doteqdot \pm 1 / 100, \pm 1 / 50, \pm 1 / 25$ のループ形状 


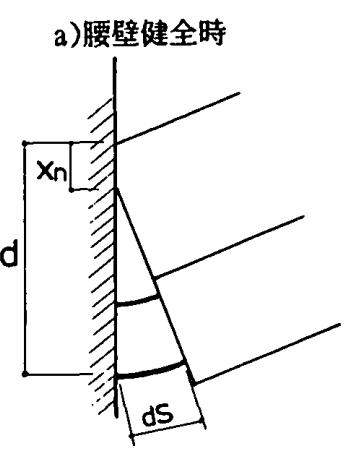

$$
\begin{aligned}
& \theta=\frac{d S}{d-x n} \\
& \theta=\theta^{\prime} \text { とすると } \begin{array}{l}
x n<x n^{\prime} \\
d S>d S^{\prime}
\end{array}
\end{aligned}
$$

図一3.5 はり危険断面位置の主筋
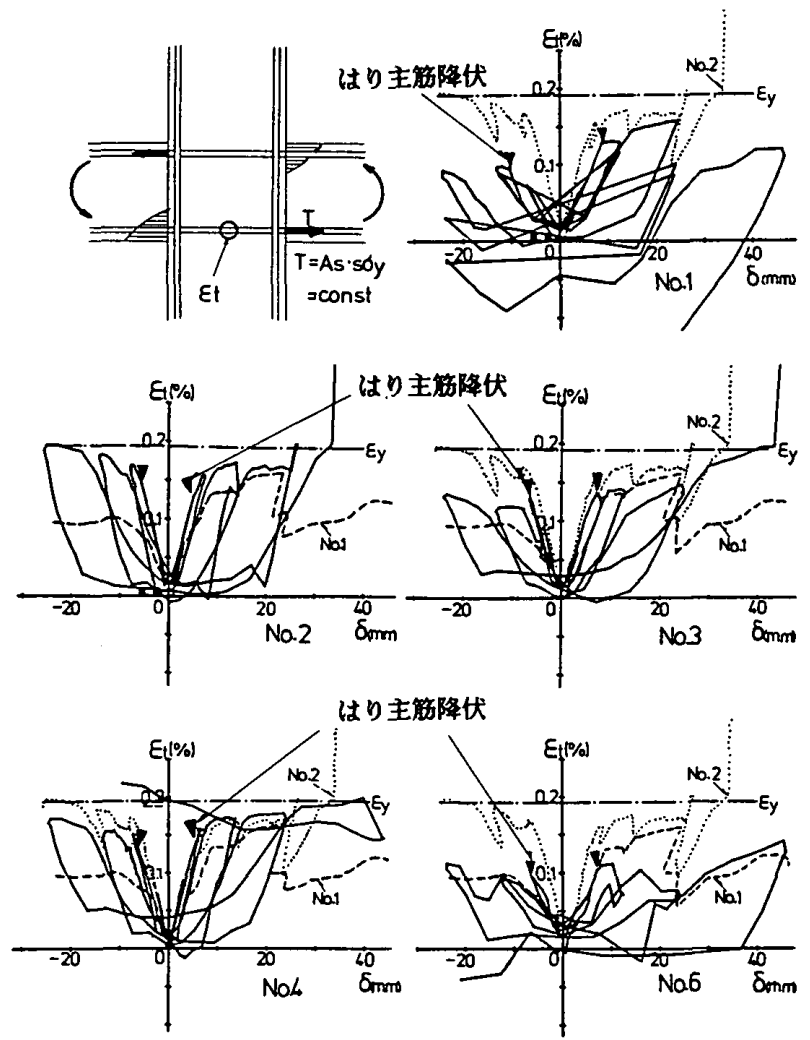

図一3.6 柱・はり接合部内のはり主筋のひずみ挙動

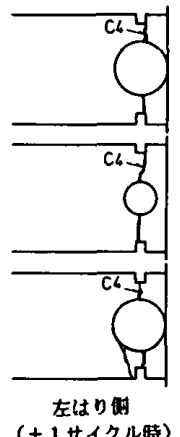

No.3

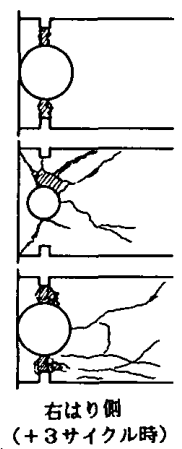

巡级: + 1サイクル時の压嫃部分

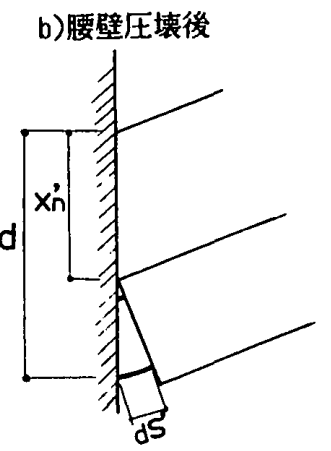

$\theta^{\prime}=\frac{d S}{d-x_{n}}$

それぞれ 3 回の繰り返し加力を行っている点がほかの試 験体と異なっている。No.1で見られるピンチ現象はこ の影響によるものと思われる。

\section{3 .2 はり・柱接合部内の主筋のひずみ}

図一3.6にはり・柱接合部のはり下端主筋中央のひず みと層間変形の関係を No. 1 No. 4 と No. 6 について示 す。田は左右はりの柱境界面位置で下端主筋が降伏した 時である。柱との境界面で主筋が降伏し，接合部内のは り主筋に伝達される応力が一定となるにもかかわらず接 合部内のひずみが増加するのは，正負繰り返し加力や変 形の増加により付着劣化が促進されるためである。

No. 1 は+3サイクルで降伏ひずみの $65 \%$ と No. 2 よ り小さいが, +4 サイクルではNo.2 に近いものとなっ ている。最終サイクルでひずみがかなり小さくなってい るのは， $R=-1 / 50$ での 3 回目の繰り返し時にひずみ が負であることとかかわりがあると考えられる。No. 5 とほぼ同じひずみ状況であったNo. 3 は， +4 サイクル まではNo.1に近いが，最終サイクルで降伏している。 No. 2 と No. 4 はほぼ同じ状況で最大耐力時では降伏ひ すみの $90 \%$ になり，最終サイクルに降伏している。最 終サイクルでNo. 4 が No. 2 ほどのピンチ現象を生じな かったのは，圧壊の進展の状況により中立軸に差が生じ 図一 3.5 に示すようにはり主筋に強制される伸びが No.4の方が小さくなりやすいためと考えられる。No. 6 は全般的に No.1 と比べて顕著な違いは見られず，最終 サイクルで増加するものの降伏はしていない。また， $\delta$ $=20 \mathrm{~mm}$ レベル $(R \doteqdot 1 / 50)$ までの間で，No.1のひず みが No. 6 より若干大きくなっている点は，前述した繰 り返し回数の違いによるものと思われる。なお，図一 3.6 に示されていない試験体については, No. 5 はNo. 3 と, No.7 はN 0.6 とそれぞれほぼ同様な傾向を示し， No. 8 は, No. 3 とNo. 6 の中間の挙動を示している。

\section{4 構造目地の破壊状況}

構造目地部の破壊状況を図一 3.7 に示す。

円形空洞目地No. 3 No.5：右はり は，ハッチした部分が+1サイクルで圧 壊したものである。No. 3, No. 5 は最小 残存部が腰壁頂部から下方に $3 \mathrm{~cm}$ 程度 圧壊し，No. 4 は円形空洞の内側が腰壁 頂部表面でわずかにはく落したのみで あった。+3サイクルでは，No. 3 は破 壊が目地の最小残存部のみであったのに 対してNo.5は腰壁に進展している。 No. 4 は最大耐力時に最小残存部が完全 に圧壊したのではなく，腰壁に広がる破 壊となった。左はりは，+1サイクルで 生じたひび割れであるが, No.5で折り 曲げ配笳の影響で若干異なっているもの

C1: 一面世ん断Uと㓤n C2. 面外曲げひひ剿n C3. 压㜚せん断Uと剂 によるひひ揢们 
の，いずれも目地最小残存部に曲げ材の引張縁のひび割 れとして生じたものである。

一面せん断および王縮せん断目地 No.6〜No.8：右は りでは, +1サイクルでいずれも目地にせん断ひび割れ が生じたが, 発生時の荷重・変形はNo.7, No.6, No. 8 の順に大きい。No.6は目地にせん断ひび割れが 生じた次のステップで面外曲げひび割れが生じたが，こ れは折り曲げられた腰壁横筋の影響によるものであると 思われる。左はりでは, +1 サイクルでNo.6, No. 8 は 矩形欠損側から反対側腰壁面に曲げ材としての引張ひび 割れが生じ，一面せん断長さが小さいNo.7では二つの 矩形欠損間に生じた。左はりの場合もー1 サイクルにな ると, 各試験体とも一面せん断ひび割れを生じているが, No. 7 では発生時の荷重・変形が右はりに比べてかなり 大きくなっている。これは，+1サイルに生じたひび 割れの閉鎖が遅れたためと考えられる。

\section{5 構造目地の破壊の検討}

腰壁が圧縮側となる曲げを受ける側の目地が圧壊開始 または一面せん断ひび割れを生じた時の荷重と変形およ びひずみ注3)を表一 3.1 に示す。実験では, 腰壁頂部表面 のひずみは直接測定しなかったが, 腰壁上方にセットさ れた 2 段の変位計で図一 3.8 に示すように直線補間して 求めた。このひずみを文献 16）で報告したひずみと比 較すると，右はりについてはNo. 3 を除きいずれも本実 験值が小さい。一方，左はりについては，No.6〜No.8 のひずみがほかに比べて著しく大きな值となっている。 この原因として, 腰壁が引張側となる前の加力サイクル 時に生じた面外曲げひび割れ等が影響し，一面せん断ひ

表一3.1 目地破壊開始時のひずみ

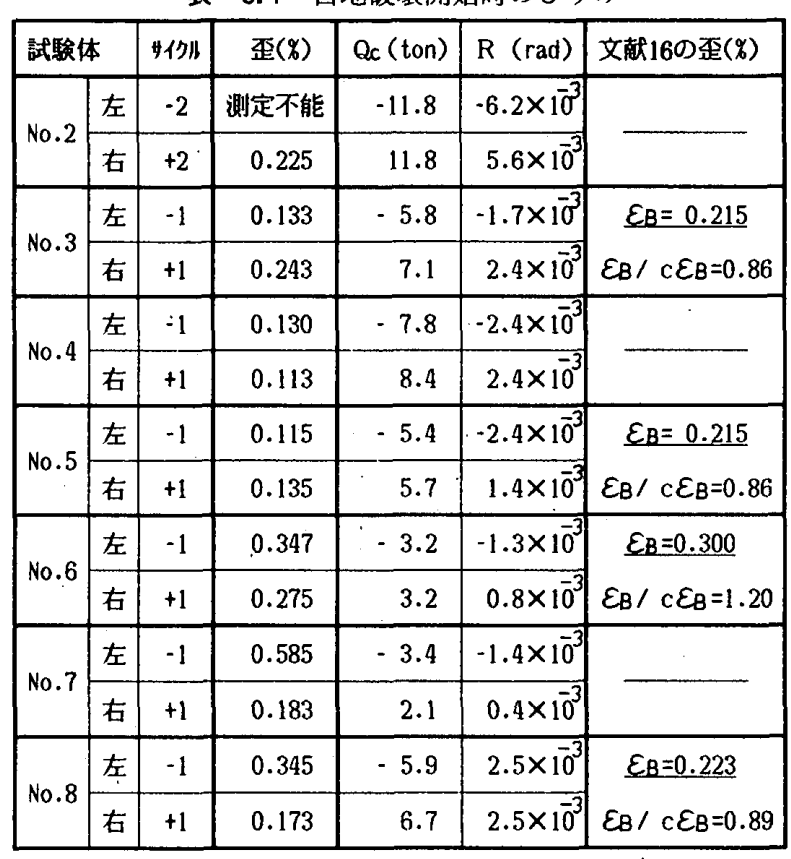

注3）柱と腰壁との間の目地を含む水平方向 $10 \mathrm{~cm}$ 間のひすみ測定方法は, 図-2.6 参照

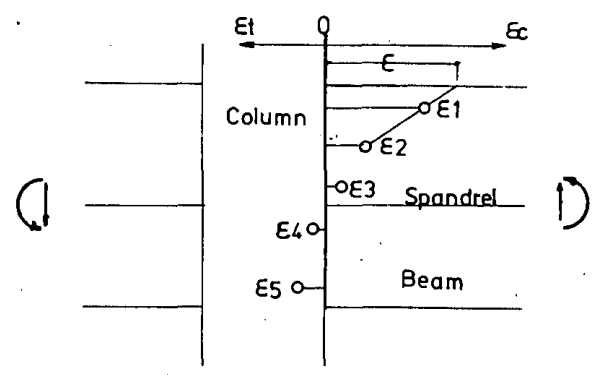

図一3.8 目地破壊開始時のひずみの算定

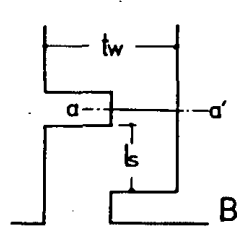

$F_{\mathrm{C}}=283 \mathrm{~kg} / \mathrm{cm}^{2}$ $F_{t}=1.8 \cdot \sqrt{F C}$ $\tau_{0}=0.13 F \mathrm{C}$

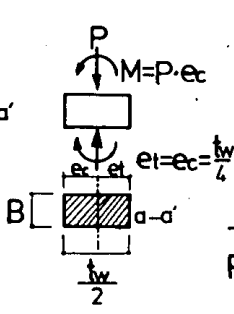

$B=1 . A=\frac{1}{2} t w B$

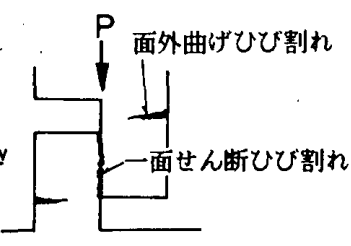

$P_{\text {scr }}=l_{s} \cdot B \cdot \tau_{0}$
図一3.9 目地部ひび割れ強度の算定方法

表一3.2 目地部のひび割れ過程

\begin{tabular}{|c|c|c|c|c|}
\hline 試験体 & $\begin{array}{l}\text { Ps.crark } \\
\left(\mathrm{kg} / \mathrm{cm}^{2}\right)\end{array}$ & $\begin{array}{l}\text { PM.crack } \\
\left(\mathrm{kg} / \mathrm{cm}^{2}\right)\end{array}$ & $\begin{array}{l}\text { 予想される } \\
\text { び割れ過程 }\end{array}$ & 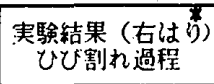 \\
\hline No. 6 & 138 & 57 & 曲げーせん断 & せん断・曲げ同時 \\
\hline No. 7 & 77 & 57 & 曲げ ↔せん斯 & せん断のみ \\
\hline
\end{tabular}

*：左はりは、+サイクルに曲げ材としてのひど割机が生したたため提示て きず。

表一3.3 目地部閉塞時の層間変形角

\begin{tabular}{|c|c|c|c|c|}
\hline & $\frac{\mathrm{No} \cdot 6}{\mathrm{rad}}$ & No. 7 & \begin{tabular}{|c|}
$\mathrm{No} .8$ \\
$\mathrm{rad}$
\end{tabular} \\
\hline \multicolumn{2}{|c|}{ 計算値 ${ }^{5)}$} & $2.7 \times 10^{-2}$ & $5.3 \times 10^{-2}$ & $2.7 \times 10^{-2}$ \\
\hline \multirow{2}{*}{ 実験値 } & 右はり & $3.2 \times 10^{-2}$ & - & $3.2 \times 10^{-2}$ \\
\hline & 左はり & $\longrightarrow$ & - & $3.4 \times 10^{-2}$ \\
\hline
\end{tabular}

び割れの発生が遅れたことが考えられる。

一面せん断目地の場合には，その応力伝達形式の特性 によって図一 3.9 のように一面せん断ひび割れ以外に面 外曲げひび割れが生じることがある。そこで，No.6, No. 7 試験体を対象に腰壁の高さ方向単位長さ当たりの 目地の面外曲げひび割れ強度 PMCr と一面せん断ひび割 れ強度PScr を同図に示すようにして求めた ${ }^{16)}$ 。その結 果を表一 3.2 に示す。計算値は, いずれも P P Cr が小さ く面外曲げひび割れが先行する結果となるが, 実際には, No. 7 では, 一面せん断ひび割れだけが生じて, 面外曲 げひび割れは生じておらず，面外曲げひび割れ強度の計 算方法にさらに検討の余地が残されている。

\section{6 一面せん断目地の閉塞}

試験体 No. 6 とNo. 8 は, 層せん断力 ・ 層間変形関係 で見られたように，大変形域で構造目地幅が閉塞し，こ れによってその後, 荷重が上昇しだ。市之瀬等は, 腰壁 
を切断した試験体で腰壁が柱と接触するときの層間部材 角の略算式 (3.1) を提案している5)。これによる計算 值と実験による耐力再上昇時の層間部材角を表一 3.3 に 示す。

$$
R=\frac{\text { スリット幅 }}{\text { 腰壁高さ }} \times \frac{\text { はりの内法長さ }}{\text { はり間長さ }}
$$

計算結果は，実験中に目地閉塞が生じたNo. 6 および No. 8 に対して若干小さめとなっているが, 目地幅が ほかの目地に比べて広く, 実験中（最大部材角：約 $4 \times$ $10^{-2} \mathrm{rad} . ） に$ 目地部開塞による荷重再上昇は生じていな いNo.7の場合を含め, 一面せん断または圧縮せん断目 地の閉塞についても, 市之瀬等の推定方法が有効である ことを示している。

\section{4. 剛性・強度の検討}

\section{1 初期剛性}

試験体骨組の初期剛性について実験値と計算値を表一 4.1 に示す。実験値は, 曲げひび割れ発生前における層 せん断力・変形曲線の初期剛性である。計算値は, はり 理論と弾性 FEM 解析で求めた。はり理論による計算 值は, 図一 4.1 に示すように柱・はりに剛域を仮定し, 鉄筋も考慮している。弾性 FEM 解析による計算値は, すへてての鉄筋を無視している。計算での目地部の厚さと 幅に関しては, はり理論の場合, 円形空洞目地では厚さ は最小実断面厚, 幅は直径とし, 一面せん断目地では目 地部のコンクリートと腰壁横筋を無視し完全スリットと 仮定した。弾性 FEM 解析の場合, 図一4.2 に示すよう に目地部の圧縮剛性が等価になるような壁厚を部分モデ ルを用いて別途 FEM 解析で求め, その值を用いた。 等価壁厚比を表一 4.2 に示す。

実験值で，No. 4 がNo. 2 より，また，No. 7 がNo. 6 よりやや大きくなっているが, 加力初期の微小変形レべ ルで, 変位計の測定值が小さいので実験值にある程度の 幅を考えると, 全体的に実験値と計算値はほぼ対応して いると思われる。計算值では, はり理論で部材フェース から剛域端までの距離を, それぞれ $D c / 4, D c / 2$ と仮 定した計算値 I と II との差は約 $6 \%$ 程度であり, 計算

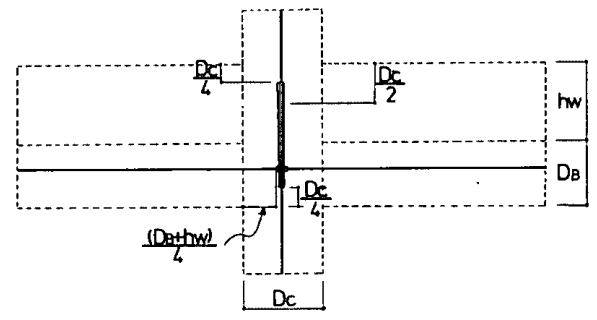

図一4.1 仮定した剛域

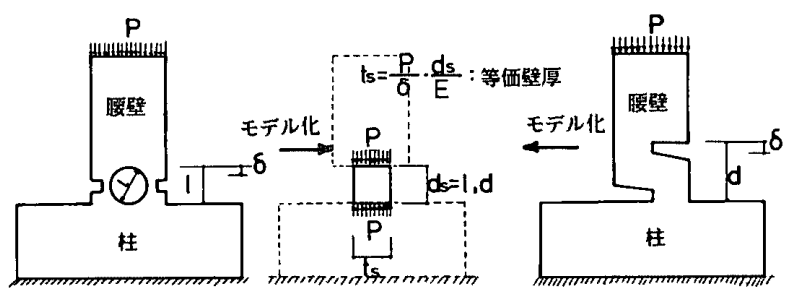

图一4.2 等価剛性壁厚の算定方法

表一4.2 用性計算に用いた壁厚比

\begin{tabular}{|l|l|l|l|l|l|l|}
\hline & No.3 & No.4 & No.5 & No.6 & No.7 & No.8 \\
\hline はり理論 & 0.28 & 0.49 & 0.28 & 0.00 & 0.00 & 0.28 \\
\hline F EM & 0.49 & 0.66 & 0.49 & 0.15 & 0.12 & 0.28 \\
\hline
\end{tabular}
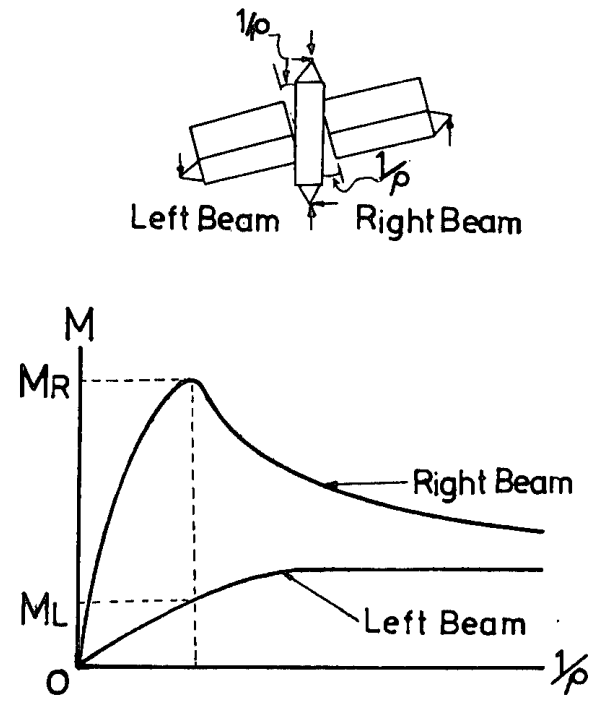

$\max \left(M_{R}+M L\right)$

图一4.3 腰壁付はりの $M-1 / \rho$ 関係

表一4.1 骨組の剛性および強度

\begin{tabular}{|c|c|c|c|c|c|c|c|c|c|c|c|c|c|}
\hline \multirow[b]{2}{*}{ 試験体 } & \multicolumn{4}{|c|}{ 初期 骩 $(\mathrm{t} / \mathrm{cm})$} & \multicolumn{5}{|c|}{ 最大耐力 (ton) } & \multicolumn{4}{|c|}{ 接合部Uと割弡強度 $\left(\mathrm{kg} / \mathrm{cm}^{2}\right)$} \\
\hline & 实龭值 & 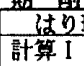 & 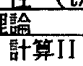 & $\begin{array}{l}\text { FEM } \\
\text { 解析值 }\end{array}$ & 正加力時 & 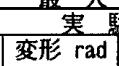 & 值 & 変形 $\mathrm{rad}$ & 計算値 & $\underset{\mathrm{D}}{\mathrm{De}}=$ & $\begin{array}{c}\mathrm{De}= \\
\mathrm{Db}+\mathrm{h} w / 2\end{array}$ & $\begin{array}{l}\text { D e }= \\
\text { Dbthw }\end{array}$ & 計算值 \\
\hline No.1 & 28.7 & 23.2 & 22.1 & 24.7 & +5.80 & $+20.0 \times 10^{3}$ & -5.35 & $-19.8 \times 10^{-3}$ & 5.09 & 28.8 & - & - & \\
\hline No.2 & 96.1 & 81.5 & 76.0 & 81.6 & +13.36 & $+11.4 \times 10^{-3}$ & -12.40 & $-11.5 \times 10^{3}$ & 12.48 & 77.5 & 39.4 & 23.1 & $\tau=\mathrm{Ft} / \sqrt{1+\sigma_{0} / \mathrm{Fc}}$ \\
\hline No.3 & 79.7 & 64.9 & 61.4 & 75.4 & +9.07 & $+5.9 \times 10^{-3}$ & -9.18 & $-5.3 \times 10^{-3}$ & 9.31 & 56.8 & 28.9 & 17.0 & $\tau=35.6 \mathrm{~kg} / \mathrm{cm}^{2}$ \\
\hline No.4 & 111.5 & 73.2 & 68.7 & 78.4 & +12.19 & $+8.0 \times 10^{-3}$ & -11.06 & $-10.5 \times 10^{-3}$ & 11.01 & 71.3 & 36.3 & 21.3 & 但し \\
\hline No.5 & - & 64.9 & 61.4 & 75.4 & +8.70 & $+4.5 \times 10^{-3}$ & -8.14 & $-6.0 \times 10^{-3}$ & 7.76 & 44.6 & 22.7 & 13.3 & $\mathrm{Fc}=283 \mathrm{~kg} / \mathrm{cm}^{2}$ \\
\hline No. 6 & 40.0 & 50.2 & 48.0 & 60.9 & +6.32 & $+9.6 \times 10^{-3}$ & -5.58 & $-10.2 \times 10^{3}$ & 5.75 & 38.4 & 19.6 & 11.5 & $\mathrm{Ft}=1.6 \cdot \sqrt{\mathrm{FC}}$ \\
\hline No.7 & 69.9 & 50.2 & 48.0 & 58.1 & +5.92 & $+10.5 \times 10^{-3}$ & -5.63 & $-10.2 \times 10^{-3}$ & 5.47 & 35.5 & 18.1 & 10.6 & $\sigma_{0}=20 \mathrm{~kg} / \mathrm{cm}^{2}$ \\
\hline No.8 & 89.9 & 62.6 & 59.3 & 69.5 & +7.95 & $+5.3 \times 10^{-3}$ & -7.71 & $-6.0 \times 10^{-7}$ & 7.98 & 49.3 & t 25.1 & 14.7 & \\
\hline
\end{tabular}


値 I が FEM 解析值に近い。なお, No.6, No.7ではり 理論値と FEM 解植值との差が, ほかの試験体に比べ てやや大きくなっている点は, はり理論值の計算で目地 部を完全スリットと仮定したことによるものと考えられ る。

\section{2 最大耐力}

各試験体の最大層せん断力の実験值と計算値を表一 4.1 に示す。計算は, 試験体がはり降伏型に設計されて いることから，図一 4.3 に示すように加力方向により断 面性能の異なる左右はりのモーメント一曲率関係を梅村 博士の $\mathrm{e}$ 関数法により求め, 左右はりの曲げ危険断面位 置での曲率が同等として，左右はりの抵抗モーメントの 和が最大となる值により求めた。はりのモーメント一曲 率関係を求める際, 目地部の抵抗断面に関しては, 円形 空洞目地と圧縮・せん断目地は最小実断面とし, 一面せ ん断目地では一面せん断面上で破壊するものとして，こ のせん断強度と同等な強度を有する置換圧縮壁厚を仮定 した。また，折り曲げ配筋されたNo. 5 とNo. 6 の腰壁 横筋は，抵抗しないものとした。

実験值で, 正加力時と負加力時の耐力には絽り返しに よる影響が生じており, 正加力時の耐力が負加力時より 全般的に若干大きい。各試験体間では, No. 2 が最も大 きいが，No.4の正加力時と No. 2 の負加力時はほぼ同 じである。目地部の圧縮抵抗最小断面が同じである No. 3, No. 5, No.8では, 圧縮せん断目地のNo.8が 最も小さく, 目地形状の違いによる差が明らかに生じて いる。一面せん断目地の No.6, No. 7 は, 腰壁無しの No.1にかなり近い。

実験値と計算値の対応については，左右はりで断面性 能がことなる本実験で, 左右はり先端の変形を同変形に して加力した実験值とはり危険断面位置での曲率を同等 と仮定した計算値とは，直接比較はできないが，計算值 は，全般的に負加力時の実験值にかなり近い結果となっ ている。

\section{3 柱はり接合部パネルのせん断ひび割れ強度}

各試験体とも荷重・変形レベルには差はあったが，い ずれも接合部パネルにせん断ひび割れが発生した。左右 はりの断面性能が異なる接合部のひび割れ強度・終局耐 力については研究がなく不明な点が多いが，ここでは， 図一4.4 に示すように接合部パネルゾーンを種々仮定し て, 整形な断面のはり・柱の接合部に対して提案されて いる平均せん断応力度式 ${ }^{17)}$ で得られる值を実験值とし た。その結果を表一 $4: 1$ に示す。計算値は，接合部の主 応力度が, コンクリートの引張強度 $\mathrm{Ft}$ に達した時にひ び割れが生じるとして, 同表中の式で求めた。

実験值と計算值を比較すると一面せん断目地の No.6, No.7については計算値はパネルゾーンを $D e=$ $D b$ とした実験值に近く, 腰壁なしのNo. 1 に近い結果

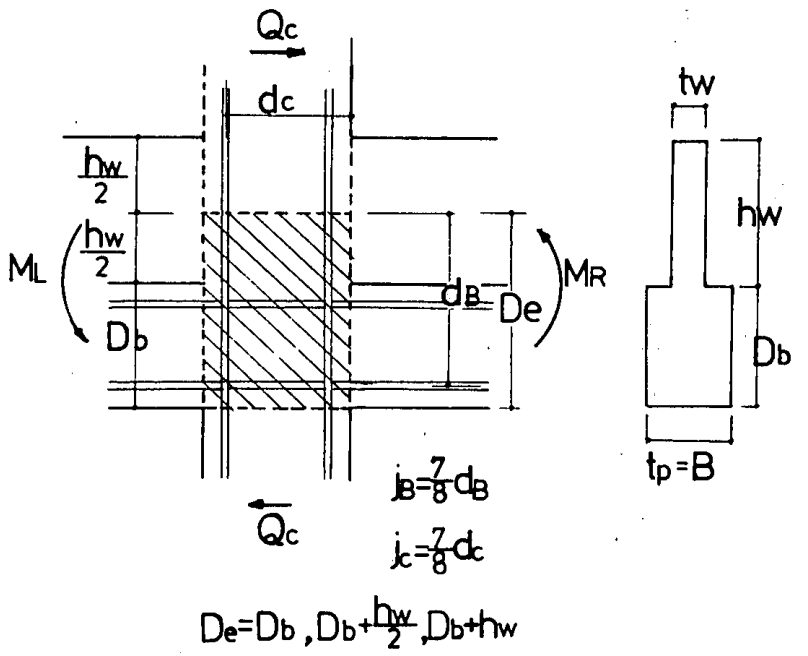

$$
p \tau=\left(M_{L}+M_{R}-Q_{C} \cdot j_{C}\right) / t_{p} \cdot j_{B} \cdot j_{C}
$$

図一4.4 接合部パネルのひび割れ強度の算定方法

となっている。また，腰壁の拘束が大きい No. 2, No. 4 では, $D e=D b+(\mathrm{hw} / 2)$ とした実験值に計算值は近い。 No. 3 , No. 5 , No. 8 の計算値は, $D e=D b$ と $D e=D b$ $+(\mathrm{hw} / 2)$ の実験値の中間にある。

以上の計算值と実験值との対応から想定されるパネル ゾーンの大きさは, 図一 3.1 に示したバネルのせん断ひ び割れとも定性的にほぼ一致している。

\section{5. 結 び}

種々の構造目地を有する十字形試験体の破壊実験の結 果の内, 構造目地が骨組の力学的特性および破壊性状に 及ぼす影響について検討した結果を以下にまとめる。

1. 円形空洞目地の試験体の復元力特性は, 目地の残存 率と配筋の違いにより異なり, 残存率が大きい場合 には最大耐力以降の耐力低下が大きい Type I の復 元力特性を示すが, 残存率を小さくすると, Type II の復元力特性に近くなる。

2. 一面せん断目地の復元力特性は, 目地部がかなり早 期に破壊し，腰壁の存在が骨組の保有耐力にほとん ど影響を与えないはり降伏型の復元力特性 Type III を示す。

3. 圧縮せん断目地の場合には, 残存率が等しい円形空 洞目地より目地の耐力が小さく, 復元力特性 Type IIに属する。

4. 各試験体のひび割れ状況も構造目地の種類により異 なったが, 円形空洞目地の No. 3 と一面せん断目地 で腰壁横筋を配筋しなかったNo.7 は, 腰壁の破壊 が目地部に集中しており，破壊後の補修の観点から 優れているものと考えられる。

5. ループ面積・ループ形状・接合部内のはり主筋のひ ずみ状況に関しては, 目地形式の違いによる著しい 差は見られなかった。また，No.1とほかの試験体 との差が顕著でなかった点に関しては，繰り返し加 
力方法の違いもあるが, 柱せいが実状のプロポー ションより大きく, はり主筋の接合部内での付着劣 化があまり生じなかったことによる影響が大きいも のと考えられる。

6. 一面せん断目地のひび割れ強度については, 文献 16 の方法では, 一面せん断ひび割れ強度に対して 面外曲げひび割れ強度を相対的に低く評価する。

7. 一面せん断目地と圧縮せん断目地の閉塞時の変形 は，市之瀬等の方法でほぼ推定しうる。

8. 構造目地を有する骨組の初期剛性は, 円形空洞目地 と王縮せん断目地では目地部の壁厚を最小残存厚さ とし，また，一面せん断目地では，その部分を完全 スリットとして, 変断面材としてのはり理論によっ てほぼ推定できる。

9. 構造目地形式の違いは, 柱・はり接合部のパネルせ ん断ひび割れ性状にも影響を及ぼす。一面せん断目 地の場合には, 腰壁がない骨組としての接合部パネ ルと仮定して, パネルのせん断ひび割れパターンと せん断応力度の検討が可能であるが, 円形空洞およ び圧縮せん断目地の場合には, パネルゾーンが柱上 方に拡大する傾向にあり，より詳細な検討を行うた めにはさらに多くの実験が必要とされる。

\section{参考文献}

1）例えば, 1968 年十勝沖地震災害調查報告, 日本建築学会 編

2）例えば, 東 洋一, 大久保全陸, 江戸宏彰: 静加力試験 による腰壁，たれ壁，そで壁付き鉄筋コンクリート柱の 破壊性状之履歴曲線, 日本建築学会論文報告集, 第 169 号, pp. 1-8, 昭和 45 年

3）日本建築学会 : 学校建築計画, pp.617-650, 丸善, 昭和 46 年

4）本岡順二郎, 丸田 操, ほか：光庭方式による学校建築 に関する研究 (その 2$)$, 日本建築学会学術講演梗概集, pp. 1245-1246，昭和 54 年 9 月

5）市之瀬敏勝, 青山博之：腰壁を切断した鉄筋コンクリー 卜造はり柱接合部の実験的研究，コンクリート工学,
Vol. 20, No. 7, pp. $97-110$

6）川股重也, 大沼正昭：東北工大 5 号館腰壁絶縁の効果, 日本建築学会学術講演梗概集, 昭和 56 年 9 月, pp. 1453-1454

7）小倉弘一郎, 向井 毅：腰壁・たれ壁と柱を絶縁する補 強法・学校施設の耐震診断容量作成のための調查研究報 告書 (学校建築委員会・第 5 小委員会), 昭和 49 年 3 月

8）狩野芳一, 高木仁之, 海平孝雄：腰壁付き柱の破壊実験, 日本建築学会学術講演梗概集, 昭和 57 年 10 月, pp. 1521-1522

9）小川 徹, 山口育雄, 小林昌一, 大久保全陸: 雑壁を含 む $\mathrm{RC}$ 骨組に関する研究 (その 1 )，日本建築学会学術講 演梗概集，昭和 58 年 9 月, pp. 1685-1686

10）武田 寛：鉄筋コンクリート造雑壁付き柱の耐力及び変 形性状に関する実験的研究，日本建築学会学術講演梗概 集, 昭和 59 年 10 月, pp. 1753-1754

11）平石久宏, 川島俊一, 佐藤彰芳, 狩野芳一：鉄筋コンクリー 卜造腰壁付き柱に設けたスリットの効果に関する研究， 日本建築学会構造系論文報告集, 第 362 号, 1986 年 4 月, pp. 83-92

12）遠藤利根穂, 津村浩三, 周 小真, 加藤 聡: 炻器質材 を利用して腰壁垂壁付き柱における脆性破壊を防止する ための実験的研究, 日本建築学会学術講演梗概集, 昭和 57 年 10 月, pp. 1293-1294

13）大久保全陸, 塩屋晋一, 波多江英治, 小川 徹：構造目 地を有する鉄筋コンクリート腰壁の収縮特性測定実験, 日本建築学会学術講演梗概集構造 II, 昭和 61 年 8 月, pp. 321-322

14）大久保全陸，塩屋晋一，波多江英治：構造目地を有する 鉄筋コンクリート骨組の設計法に関する研究（その5）, 日本建築学会学術講演梗概集構造 II, 昭和 60 年 10 月, pp. $467-468$

15）小林 裕, 小谷俊介：鉄筋コンクリート造柱はり接合部 内のはり主筋付着に関する研究（その1)，日本建築学会 学術講演梗概集, 昭和 58 年 9 月, pp. 1819-1820

16）大久保全陸, 塩屋晋一, 山本 潔：構造目地を有する $\mathrm{RC}$ 腰壁付きはり・柱十字型試験体の水平加力実験（そ の 3 ), 日本建築学会学術講演梗概集構造 II, 昭和 61 年 8 月, pp. 83-84

17）鉄筋コンクリート終局強度設計に関する資料・シリーズ 28 , 建築雑誌, 1982 年 3 月号 


\section{SYNOPSIS}

UDC : $624.02: 624.078 .012 .4: 624.04$

\section{STUDIES ON SEISMIC CHARACTERISTIC OF REINFORCED CONCRETE SPANDREL- BEAM-COLUMN SUBASSEMBLAGES WITH STRUCTURAL SLITS}

Part I -The results of lateral loading tests of spandrel-beam-column subassemblages

by Dr. MASAMICHI OHKUBO, Professer of Kyushu Institute of Design and SHIN-ICHI SHIOYA, Research Associate of Kyushu Institute of Design, Members of A. I. J.

Non-structural concrete spandrels have often been used in reinforced concrete buildings because of a building design, construction cost, and performance of exterior walls.

However, it is apparent from many earthquake experiences and such simulation tests that the concrete spandrels were not simply non-structural members but they greatly influence the failure modes and the behavior of the frame during an earthquake.

Recently, a procedure of structural design and construction, which aims to reduce the undesirable effects of spandrels to frames by adopting the joint details, so-called "Structural Slit" where the spandrel is made partially and extremely thin, are studied and used in an actual structural design.

This report is one of the studies on Structural Slit. The spandrel-beam-column subassemblages with different types of Structural Slits are tested under lateral load reversals in order to investigate the influence of the shape and the dimension of the Structural Slit on the strength and the behavior of a reinforced concrete frame. 